\title{
Dynamics of Prunus Necrotic Ringspot and Apple Mosaic Ilarviruses in Stone Fruits - A Serological Perspective
}

\author{
Shelly Kapoor ${ }^{1 *}$, Anil Handa ${ }^{1}$, Bunty Shylla ${ }^{2 *}$ and Abhilasha Sharma ${ }^{1}$ \\ ${ }^{1}$ Plant Virology Laboratory, Dr. Y S Parmar University of Horticulture and Forestry, \\ Nauni-173230, Solan, Himachal Pradesh, India \\ ${ }^{2}$ Horticulture Research and Training Station and KVK, Kandaghat, India
}

*Corresponding author

\section{A B S T R A C T}

\section{Keywords}

Prunus necrotic ringspot virus (PNRSV), Mosaic virus (ApMV)

Article Info

Accepted:

10 April 2018

Available Online:

10 May 2018
Prunus necrotic ringspot virus (PNRSV) and apple mosaic virus (ApMV) are among the most widespread and economically important ilarviruses in stone fruits. Enzyme-linked immunosorbent assay (ELISA) was used to determine the incidence of PNRSV and ApMV in peach, plum and apricot grown in the major stone fruit growing areas in the districts of Solan, Sirmour, Shimla and Kullu in Himachal Pradesh, India during active growing seasons of 2017 and 2018. Field surveys were carried out to assess the sanitary status of major stone fruits. Both ilarviruses were detected in all stone fruit species tested. Leaf samples from peach, apricot and plum were tested by ELISA for the presence of prunus necrotic ringspot virus (PNRSV) and apple mosaic virus (ApMV). The overall average infection level determined by DAS-ELISA was 11.16 percent. The most frequent virus encountered was PNRSV (9.06 percent) whereas the incidence of ApMV was 2.1 percent. This is the first large-scale study conducted on ilarviruses of stone fruits in this region of the country. Use of ELISA to monitor virus incidence in stone fruits can be put to use as an efficient and valuable tool for reducing the occurrence of ilarviruses that are transmitted by propagating material.

\section{Introduction}

Prunus necrotic ringspot virus (PNRSV) and apple mosaic virus (ApMV) are common and widespread in different stone fruits causing crop losses (Scott, 2014; Pallas et al., 2012). In India, little is known on virus diseases of stone fruit trees and records are limited on the occasional finding of ilarviruses (PNRSV and ApMV) in major stone fruits grown in India (Kapoor and Handa, 2017a; Chandel et al., 2013). Studies on the deleterious effects on the growth and yield by both viruses on various Prunus hosts have been published by a number of authors (Kapoor and Handa, 2017b; Caglayan and Gazel, 1998; Alhudaib and Rezk, 2011). Besides stone fruits, the importance of ilarviruses in apple production system has been critically revealed by (Kapoor et al., 2018). Although, ilarviruses are latent in nature, visual symptoms caused by these viruses in the peach, plum and apricots are very similar and it is difficult to differentiate the two viruses in these hosts. PNRSV and 
ApMV are members of the genus Ilarvirus, family Bromoviridae and these viruses are transmitted mechanically through grafting, pollen and seeds which is largely responsible for their fairly wide distribution (Posnette and Ellemberger, 1957; Nemeth, 1986; Diekmann and Putter, 1996; Brunt et al., 1996; Fulton, 1980; Ragozzino, 1980 and Hammond, 2011). Some of the studies on serological detection of PNRSV and ApMV in stone fruits have been investigated in India by Kapoor and Handa (2017 a, b) and Chandel et al., (2013).

The aim of the present study was to record the incidence of PNRSV and ApMV in peach, plum and apricot in the major stone fruit growing areas in the mid hill zone of Himachal Pradesh. The results obtained will be used for the selection of mother plants as the most appropriate strategy to prevent the spread of these ilarviruses.

\section{Materials and Methods}

\section{Plant material}

The surveys were carried out in stone fruit orchards in some of the main stone fruit tree growing areas in the districts of Solan, Sirmour, Shimla and Kullu in Himachal Pradesh during the active growing seasons of 2017 and 2018. The samples from peach, plum and apricot trees were collected from experimental, collection, nuclear stock and commercial orchards. Leaf samples exhibiting typical symptoms were drawn from the marked plants in the selected orchards and brought to the laboratory in separate polythene bags in an ice box so as to keep the leaf samples fresh for serological detection of Ilarviruses (ApMV and PNRSV). Trees existing in the surveyed orchards, experimental collection and nuclear stock were critically observed for recording the symptoms on each cultivar. Symptomatic trees of different cultivars were marked for recording the observations on the symptoms as well as serological detection of viruses by following enzyme-linked immunosorbent assay (ELISA) technique. Alkaline phosphatase (ALP) based direct form of double antibody sandwich (DAS) ELISA was used to detect the infection of the ilarviruses.

\section{DAS-ELISA}

Infected leaves showing symptoms of chlorotic and necrotic rings, flecking, shot holes, oak leaf pattern and yellowing collected from random branches of a single tree were considered as one composite sample and brought to the laboratory in ice bucket for conducting DAS-ELISA tests as per the protocol given by Clark and Adams (1977). Wells of the microtitre plate (BIOREBA, Switzerland certified microplates) except those of the top and bottom rows and rows on the extreme left and right, were filled with $200 \mu 1$ aliquots of coating antibodies diluted in $1 \mathrm{x}$ coating buffer $(1: 1000$ ratio $\mathrm{v} / \mathrm{v})$. The plate was incubated in humid box for 4 hours at $30^{\circ}$ C. The coating antibody suspension was removed by shaking out the plate over the wash basin. The wells were filled with $1 \mathrm{x}$ PBS-Tween and kept for 2 minutes with gentle shaking. The plate was emptied and filled again with PBS-Tween. The washing was repeated three times. The test samples were grounded in $1 \mathrm{x}$ extraction buffer (1:10 ratio $\mathrm{v} / \mathrm{v})$.

All coated wells were filled with $200 \mu 1$ aliquots of test samples (each sample in duplicate) besides positive and negative control wells. The plate was incubated in humid box overnight at $4 \pm 1^{\circ} \mathrm{C}$. The washing steps were repeated as mentioned above. Alkaline phosphate (ALP) conjugated antibodies were filled in each well with $200 \mu \mathrm{l}$ aliquots after diluting it in 1x ECI (enzyme conjugated immunoglobin) buffer at a (ratio of 1:1000 v/v). The plate was incubated in humid box for 5 hours at $30^{\circ} \mathrm{C}$. The washing was done as mentioned above. 
Int.J.Curr.Microbiol.App.Sci (2018) 7(5): 947-955

Fig.1 Shot holes in plum cv. Shiro

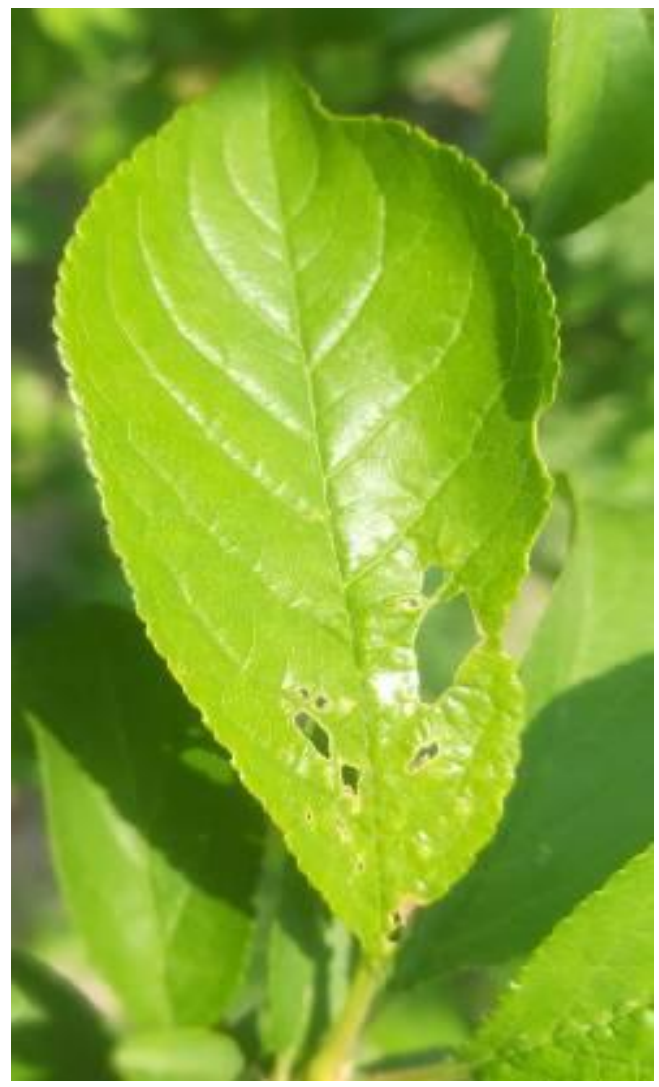

Fig.2 Chlorotic spots and yellowing in plum cv Duarte

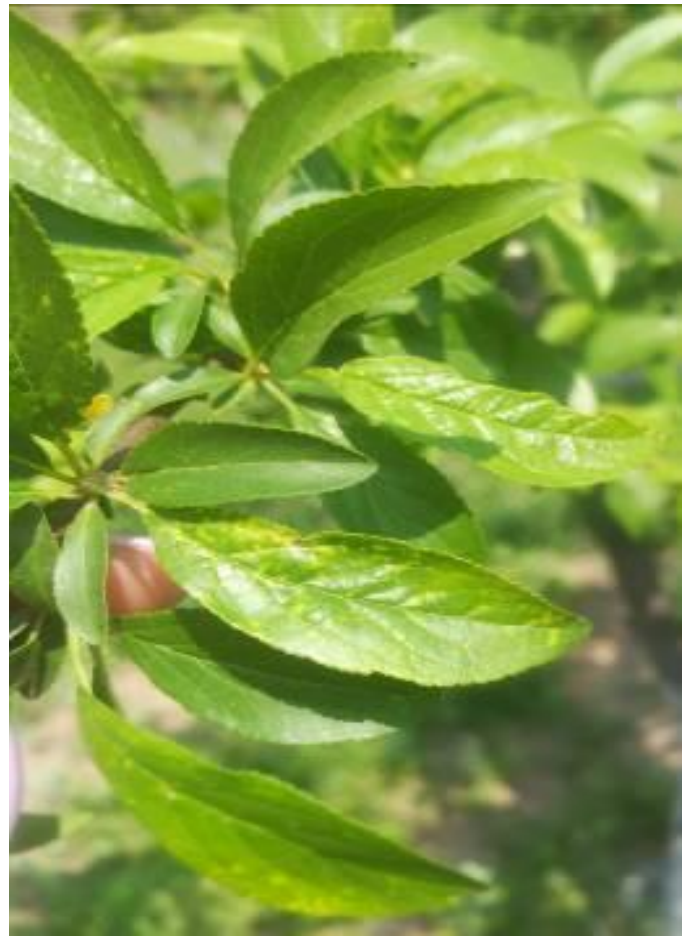


Fig.3 Chlorotic and necrotic spots accompanied by shot holes in plum cv. Fraser

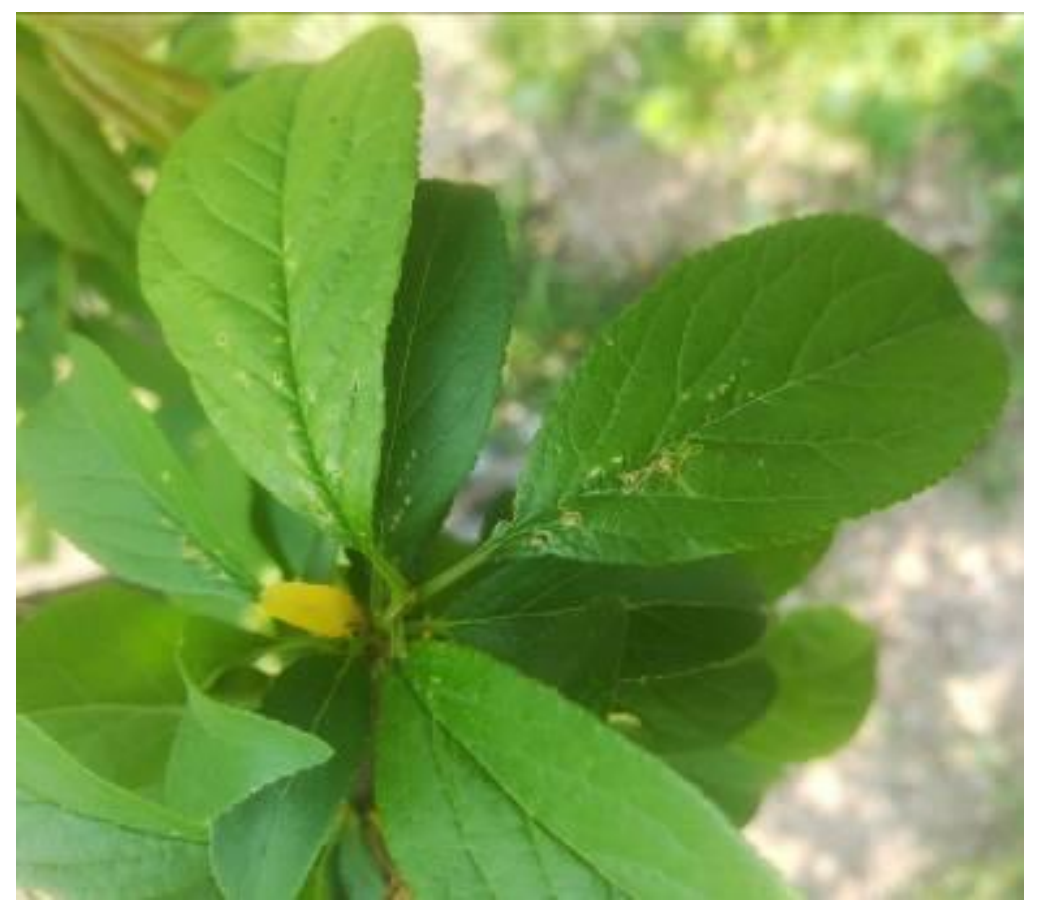

Fig.4 Chlorotic flecking and leaf deformation in plum cv. Shiro

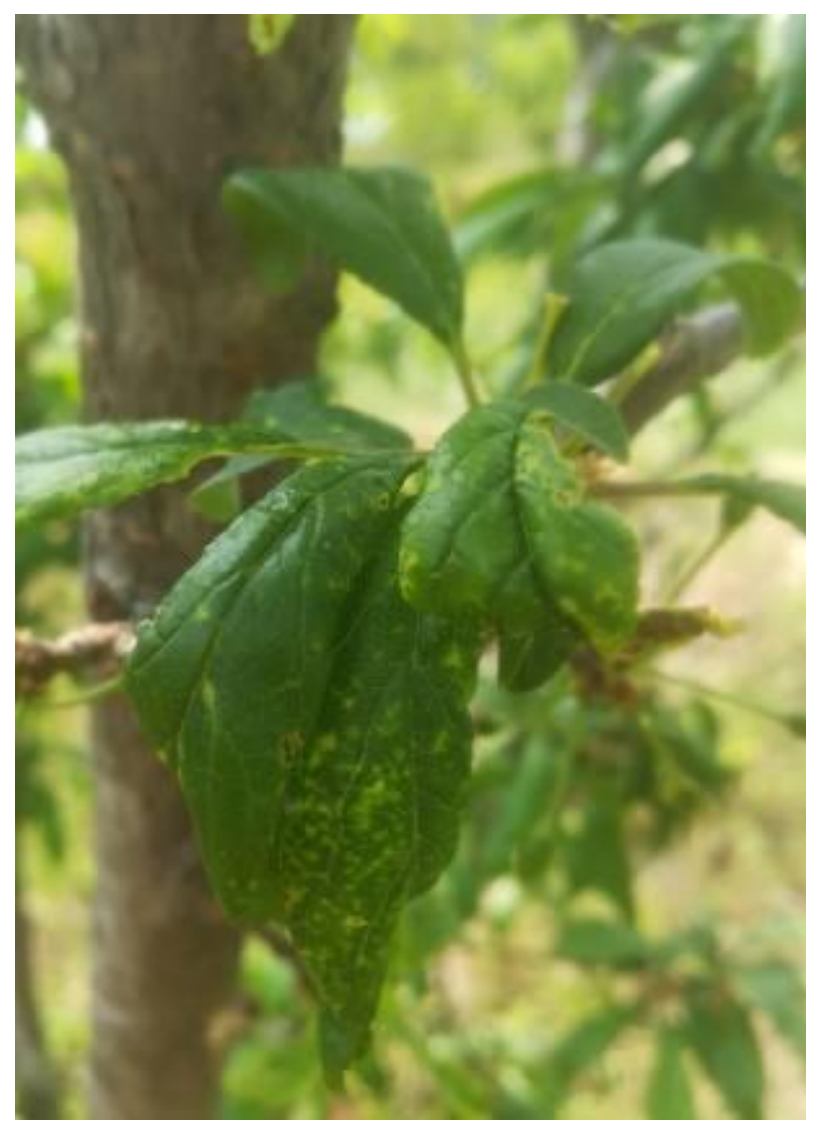


Fig.5 Initiation of oak leaf pattern and chlorotic spots in peach cv. July Elberta

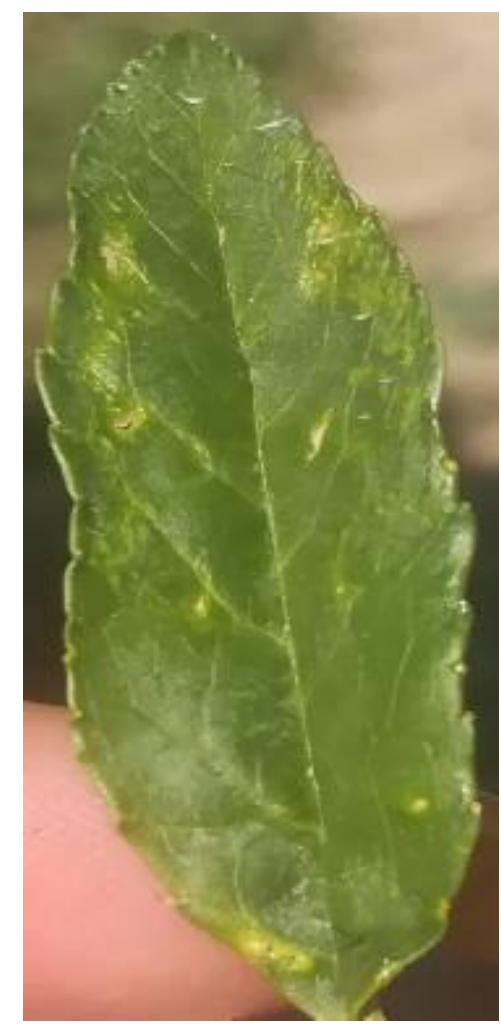

Fig.6 Deformed leaf of peach cv. Glo Haven

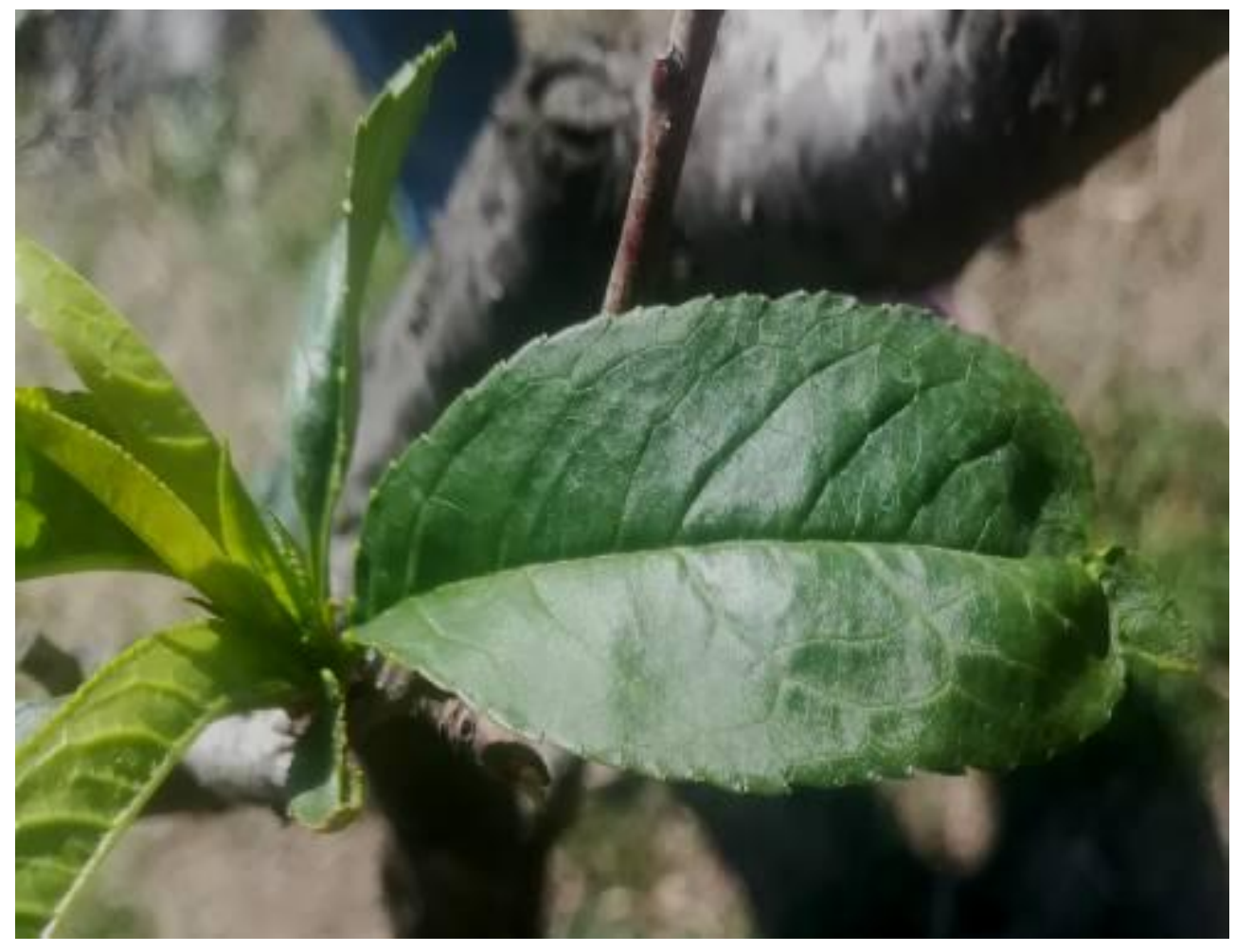


Fig.7 Shot holes and yellowing in peach cv. July Elberta

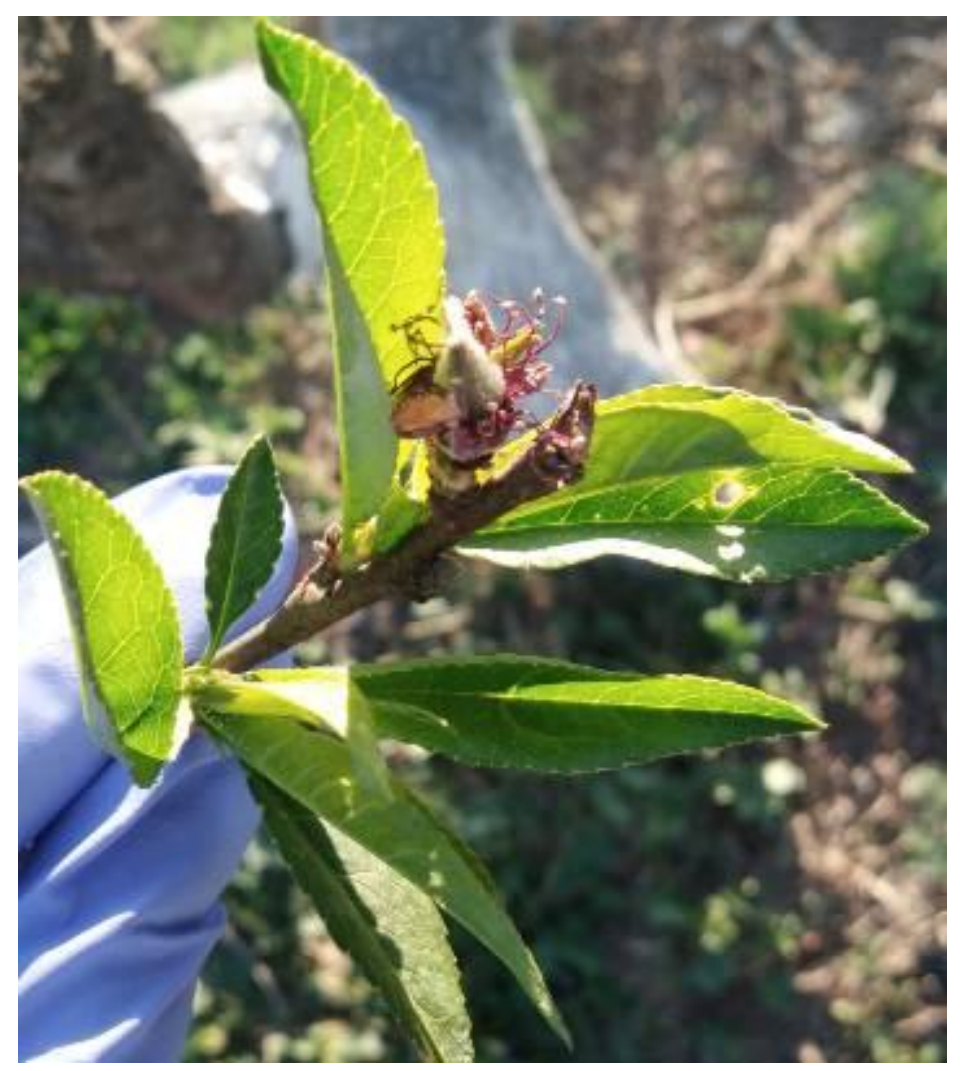

Fig.8 Interveinal chlorosis and inward rolling in apricot cv. New Castle

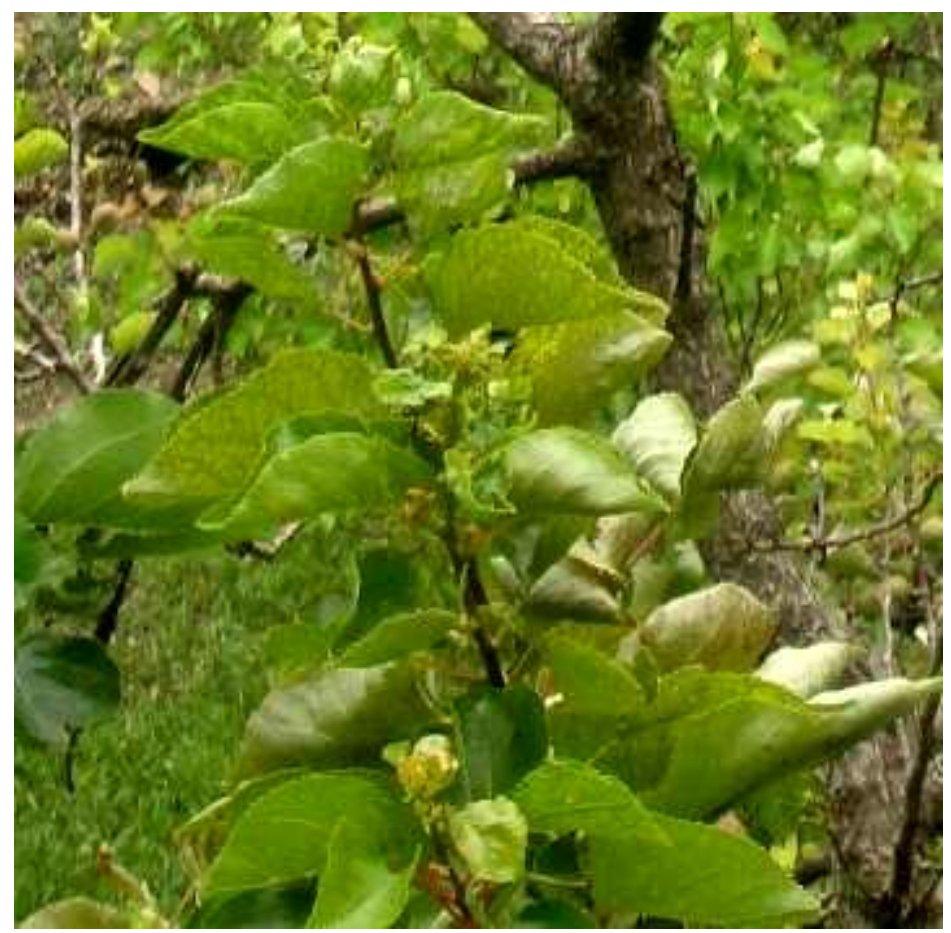


Table.1 Relative incidence of ilarviruses in stone fruits detected by ELISA

\begin{tabular}{|l|c|c|c|c|c|c|c|}
\hline Species & \multicolumn{3}{|c|}{ No. of samples Tested } & \multicolumn{2}{|c|}{$\begin{array}{c}\text { Infection } \\
\text { Rate (\%) }\end{array}$} & \multicolumn{2}{c|}{ Virus infected trees } \\
& Total & Healthy & Infected & ApMV \\
\hline Peach & 597 & 509 & 88 & 14.7 & 76 & 12 \\
\hline Plum & 381 & 361 & 20 & 5.2 & 15 & 5 \\
\hline Apricot & 273 & 269 & 04 & 4 & 1 & 3 \\
\hline Total & $\mathbf{1 2 5 1}$ & $\mathbf{1 1 3 9}$ & $\mathbf{1 1 2}$ & & $\mathbf{9 2}$ & $\mathbf{2 0}$ \\
\hline
\end{tabular}

p-nitrophenyl phosphate (pNPP) substrate was dissolved in $1 \mathrm{x}$ substrate buffer by dissolving $5 \mathrm{mg}$ pNPP tablet in $5 \mathrm{ml}$ of $1 \mathrm{x}$ substrate buffer. Each well was filled with $200 \mu \mathrm{l}$ aliquots of the substrate. The plate was kept in humid box in the dark condition at room temperature until a yellow colour was clearly visible in the positive control (usually between 30-60 minutes). The results were assessed either by visual observations or by measurement of the absorbance value of the hydrolysed substrate (p-nitrophenyl) at 405 $\mathrm{nm}$ wavelength in a microtitre plate reader (Micro Scan MS 5605A, Electronics Corporation of India Limited, Hyderabad). The results of ELISA for the detection were interpreted as per Dijkstra and Jager (1998) as samples were considered infected when their absorbance values $\left(\mathrm{A}_{405 \mathrm{~nm}}\right)$ exceeded two times the mean values of respective healthy control samples.

\section{Results and Discussion}

Some of the surveyed trees showed foliar symptoms ranging from chlorotic/necrotic spots, oak leaf pattern, puckering, flecking, distortion of leaves, shot holes and yellowing which are associated with the presence of ilarviruses and have been reported by a number of workers (Posnette and Ellemberger, 1957; Nemeth, 1986; Diekmann and Putter, 1996; Fulton, 1980; Smith et al., 1988; Brunt et al., 1996; Aouane, 2003; Hammond, 2011; Almaraz et al., 2014; Scott, 2014; and Kapoor and Handa, 2017b). As a part of the study, PNRSV and ApMV infections in peach, plum and apricot in mid hill zone in the districts of Solan, Sirmour, Shimla and Kullu of Himachal Pradesh were conducted on the basis of visual symptoms and investigated. As shown in Table 1, one or more cultivars of all these stone fruits tested positive for at least one of the two ilarviruses and the average infection level determined by ELISA was 11.16 percent. Disease incidence of individual virus was 24.8 percent for PNRSV and 7.4 percent for ApMV as indicated by visual indexing. Incidence of ilarviruses in individual stone fruit species were 14.7 percent for peach; 5.2 percent for plum and 1.4 percent for apricot on the basis of the serological detection by DAS-ELISA.

Mixed infection by PNRSV and ApMV was found to be of common occurrence particularly in case of peach trees. The present survey has shown that the level of Ilarvirus infections in stone fruit trees in mid hill zone of Himachal Pradesh is lower than that reported from other parts of the world (DiTerlizzi et al., 1992; Aouane, 2003; Polak, 2007; Matic et al., 2008; Scott 2014; Pallas et al., 2012) (Fig. 1-8).

Among the two ilarviruses detected, PNRSV was more common than ApMV. The fair sanitary status of major stone fruits grown in Kandaghat region of Solan district in Himachal Pradesh, as it appears from the present work, suggests that the implementation of a healthy plant material production system could prove highly effective for a rapid improvement of the local 
nurseries and stone fruit industry. If followed strictly, such an approach would successfully limit the dissemination of ilarviruses in this region.

\section{References}

Alhudaib, K., and Rezk, A. 2011. Prunus necrotic ringspot virus in apricot (Prunus armeniaca) and peach ( $P$. persica) newly reported in Saudi Arabia. New Disease Reports, Pp. 2326.

Almaraz, T.D., Sanchez-Navarro, J. and Pallas, V. 2014. Detection of Prunus necrotic ringspot virus in peach (Prunus persica L.) in Mexico and molecular characterization of its RNA component3. Agrociencia, 48: 583-598.

Aouane, B. 2003. Preliminary studies on stone fruit tree viruses in Algeria. Peach, 12: 56-286.

Brunt, A.A., Crabtree, K., Dallwitz, M.J., Gibbs, A.J., Watson, L. and Zurcher, E.J. 1996. Apple mosaic Ilarvirus. Plant Viruses Online: Descriptions and Lists from the VIDE Database.

Caglayan, K., and Gazel, M.H. 1998. Virus and virus-like diseases of stone fruits in the Eastern Mediterranean area of Turkey. Acta Horticulturae, 472: 527530.

Chandel, V., Rana, T. and Hallan, V. 2013. Prunus necrotic ringspot virus: incidence on stone and pome fruits and diversity analysis. Archives of Phytopathology and Plant Protection, 46: 2376-2386.

Clark, M. F. and Adams, A. N. 1977. Characteristics of the microplate method of enzyme-linked immunosorbent assay for the detection of plant viruses. Journal of General Virology, 34: 475- 483.

Di Terlizzi, B., Savino, V., Digiaro, M. and Murolo, O. 1992. Viruses of peach, plum and apricot in Apulia. Acta Horticulturae 309: 93-98.

Diekmann, M., and Putter, C.A.J. 1996. FAO/IPGRI Technical Guidelines for the Safe Movement of Germplasm No. 16. In: Stone Fruit, Food and Agriculture Organization of the United Nations, International Plant Genetic Resources Institute, Rome, Italy.

Dijkstra, J., and Jager, C.D. 1998. Practical Plant Virology: Protocols and Exercises. Springer Verlag, New York. $459 \mathrm{p}$.

Fulton, R. W., 1980. Ilarviruses In: Handbook of Plant Virus Infections and Comparative Diagnosis. (ed.): Kurstak E. North Holland, Amsterdam. Elsevier, pp. 377-421.

Hammond, R. W., 2011. Prunus necrotic ring spot virus. In virus and virus-like diseases of pome and stone fruits (eds.) Hadidi, A., Barbra, M., Candresse, T. and Jelkmann, W. APS press, St Paul, MN, USA. pp. 207-213.

Kapoor, S., and Handa, A. 2017(a). Serological Evidence for the Presence of Prunus Necrotic Ring Spot Virus in Stone Fruits with Particular Reference to Peach. International Journal of Current Microbilogy and Applied Sciences 6: 4078-4083.

Kapoor, S., and Handa, A. 2017(b). Prevalence of PNRSV in Peach orchards of Himachal Pradesh and its detection through DAS-ELISA. Journal of Plant Diseases Sciences, 12: 129132.

Kapoor, S., Sharma, A., Shylla, B. and Handa, A. 2018. Ilarviruses and the importance of certified elite planting material in apple production system-An overview. International Journal of Current Microbiology and Applied Sciences, 7: (In Press).

Matic, S., Sánchez-Navarro, J.A., Mandic, B., Myrta, A. and Pallás, V. 2008. Tracking 
three ilarviruses in stone fruit trees throughout the year by ELISA and tissue-printing hybridization. Journal of Plant Pathology, 90: 137-141.

Nemeth, M., 1986. Viruses, mycoplasma and ricketsia diseases of fruit trees. Kluwer academic publishers, Norwell, MA, USA, $841 \mathrm{pp}$.

Pallas, V., Aparicio, F., Herranz, M.C., Amari, K., Sanchez-Pina, M. A., Myrta, A. and Sanchez- Navarro, J. A. 2012. Ilarviruses of Prunus species: A continued concern for Fruit trees. Phytopathology, 102: 1108-1120.

Polák, J., 2007. Viruses of blackthorn and road-bordering trees of plum, myrobalan, sweet and sour cherries in the Czech Republic. Plant Protection Science, 43: 1-4.

Posnette, A.F. and Elenberger, E.C. 1957. The line pattern virus disease of plum. Annals of Applied Biology, 45: 74-80.

Ragozzino, A., 1980. Hazel mosaic. Acta Phytopathologica Academiae Scientiarum Hungaricae, 15: 375-378.

Scott, S.W., 2014. Viruses of peach. www.clemson.edu/extension

Smith, I.M., Dunez, J., Phillips, D.H., Lelliott, R. A. and Archer, S. A. eds. 1988. European handbook of plant diseases. Blackwell Scientific, Oxford, UK.

\section{How to cite this article:}

Shelly Kapoor, Anil Handa, Bunty Shylla and Abhilasha Sharma. 2018. Dynamics of Prunus Necrotic Ringspot and Apple Mosaic Ilarviruses in Stone Fruits - A Serological Perspective. Int.J.Curr.Microbiol.App.Sci. 7(05): 947-955. doi: https://doi.org/10.20546/ijcmas.2018.705.117 